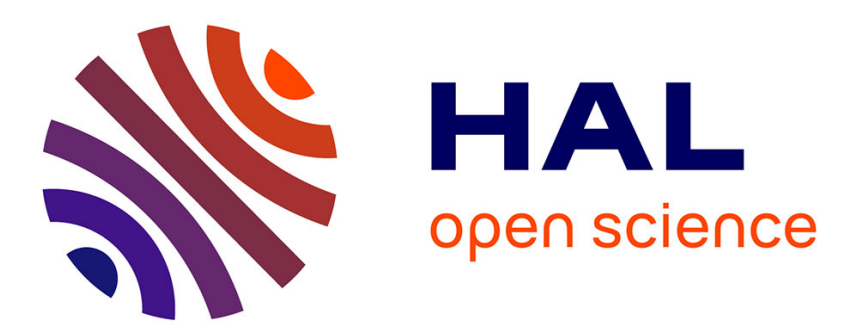

\title{
Large-scale flexuring and antithetic extensional faulting along a nascent plate boundary in the SE Afar rift
}

Bernard Le Gall, Mohamed Ahmed Daoud, Joël Rolet, Nima Moussa Egueh

\section{To cite this version:}

Bernard Le Gall, Mohamed Ahmed Daoud, Joël Rolet, Nima Moussa Egueh. Large-scale flexuring and antithetic extensional faulting along a nascent plate boundary in the SE Afar rift. Terra Nova, 2011, 23 (6), pp.416-420. 10.1111/j.1365-3121.2011.01029.x . insu-00635012

\section{HAL Id: insu-00635012 \\ https://hal-insu.archives-ouvertes.fr/insu-00635012}

Submitted on 26 Oct 2011

HAL is a multi-disciplinary open access archive for the deposit and dissemination of scientific research documents, whether they are published or not. The documents may come from teaching and research institutions in France or abroad, or from public or private research centers.
L'archive ouverte pluridisciplinaire HAL, est destinée au dépôt et à la diffusion de documents scientifiques de niveau recherche, publiés ou non, émanant des établissements d'enseignement et de recherche français ou étrangers, des laboratoires publics ou privés. 


\section{LARGE-SCALE FLEXURING AND ANTITHETIC EXTENSIONAL FAULTING} ALONG A NASCENT PLATE BOUNDARY IN THE SE AFAR RIFT

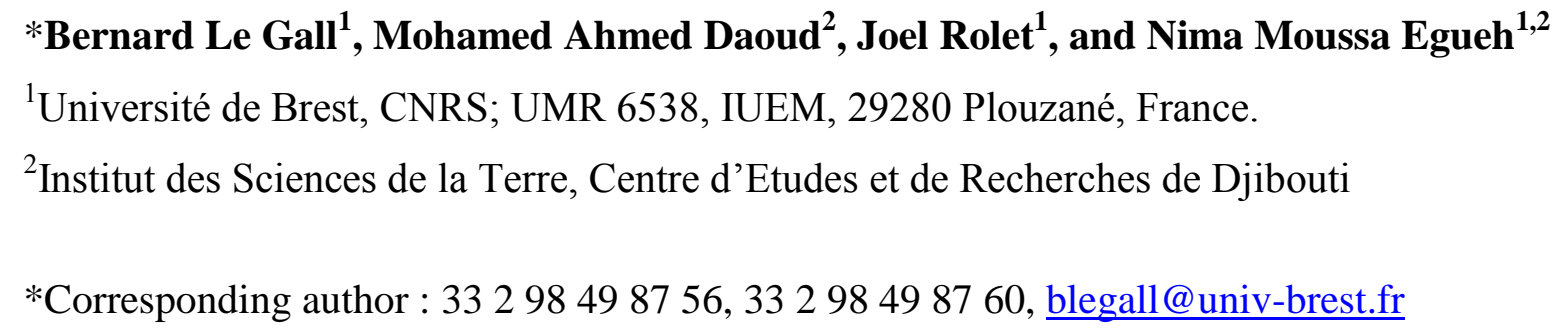

\section{ABSTRACT}

New structural data from the SE Afar margin in Djibouti leads us to discriminate two recent ( $<1 \mathrm{Ma}$ ) extensional fault networks between the Afar accreted crust, and the South Danakil Block to the east. Emphasis is placed on the N-S-oriented Makarassou fault system which dissects the prominent westward- (riftward-)facing topographic flexure between the two structural domains. The most striking characteristic of the Makarassou fault belt is a closely-spaced network of continentward-dipping extensional faults, bounding domino blocks of 3-1 Ma tilted lavas of the Stratoid series. The Makarassou fault-flexure system is interpreted as an extensional faulted monocline that developed in response to differential subsidence and crustal downwarping of the Afar magmatically-accreted transitional crust. Large-scale flexuring and associated structures along the eastern flank of the Asal-Manda Inakir incipient plate boundary are regarded as indicative of a nascent volcanic rifted margin in SE Afar.

\section{Introduction}

Since the recognition of volcanic rifted margins (VRMs) in the 1980's (see Coffin and Eldhom, 1994, for a review), the continent-ocean transition at VRMs is known to be characterized by a typical style of crustal deformation and magmatic construction. Diagnostic structures at VRMs comprise oceanward-thickening wedges of flood basalts displaying a large-scale flexure, facing towards the ocean, and further dissected by a network of continentward-dipping extensional faults (Mutter, 1984). The resulting seaward-dipping reflector sequences (SDRS) pass laterally into oceanic crust (White and McKenzie, 1989). Generally, the continent-ocean transition at VRMs is either partly under water, as along 
modern ocean margins, or severely eroded within older exposed continental margins (Klausen, 2009). Therefore, complete cross-strike transects of VRMs are rarely observed, hence leading to uncertainties about, for example, the isostatic versus tectonic origin of the overall fault-flexure pattern (Palmason, 1980; Nielsen and Brooks, 1981), or the timing and duration of brittle strain with respect to the rifting and breakup events. These structural issues are discussed here in the context of the SE Afar margin, where a magmatic fault-flexure system is exceptionally exposed along the Asal active rift (Fig. 1) and interpreted as a possible analog to a nascent VRM.

\section{SE Afar rift context}

The network of still-active tectono-magmatic axes that propagated since $3 \mathrm{Ma}$ throughout the Afar depression, ahead of the Red Sea and Aden oceanic ridges, form onshore incipient plate boundaries between Arabia, Somalia and Nubia (Fig. 1B) (Mohr, 1989). In SE Afar, the inland prolongation of the Aden ridge is outlined by the <1 Ma northerlypropagating Ghoubbet-Asal and Manda-Inakir en echelon subrifts (Manighetti et al., 1998). This modern rift axis cuts through the 3-1 Ma-old Stratoid flood basalts (Barberi and Varet, 1977) that cover most of the thin $(18-22 \mathrm{~km})$ and transitional crust of the Afar depression (Dugda and Nyblade, 2006). The SE Afar magmatically-accreted domain is flanked to the east by the South Danakil uplifted block via a prominent riftward-facing topographic scarp representing the SE Afar margin (Fig. 1). The latter is further dissected by the N-S-trending Makarassou fault system (MFS), which is generally regarded as a transfer zone linking the Ghoubbet-Asal and Manda-Inakir subrifts (Tapponnier and Varet, 1974). Mechanisms of rift propagation in SE Afar have been extensively discussed by Manighetti et al. (1998), but never addressed in terms of uplift process. The role of vertical tectonics during the recent development of the SE Afar margin is emphasized in the present work from the 3Dmorphostructural analysis of the Asal-South Danakil area.

\section{The South Danakil-Asal rift system}

Our structural study of the SE Afar margin is primarily based on 3D-morphostructural data supplied by both Landsat ETM+ (resolution $15 \mathrm{~m}$ ) and ASTER (60 x $60 \mathrm{~km})$ satellite images. ASTER digital elevation models (resolution $15 \mathrm{~m}$ ) allow estimates of (1) fault and lava dips, and (2) minimum vertical fault displacement from surface offsets along individual fault scarps. Fault lengths, deduced from map traces, are underestimated because of the loss of resolution below $15 \mathrm{~m}$ of vertical offset. Extensive field investigations did not permit the 
observation of fault surfaces with slip criteria, because the lower parts of fault scarps are systematically concealed by slope deposits, whereas their exposed upper sections usually follow basaltic columnar jointing that rarely preserves the fault slip plane. Field measurements were mostly devoted to calibrating fault and lava dips, estimated from ASTER cross-profiles. The timing and magnitude of syn- to post-Stratoid regional uplift are deduced from the spatial distribution, thickness variations and elevation of the Stratoid basalts along the SE Afar margin.

The mapped extent of the Stratoid flood basalts on the western flank of the South Danakil block suggests a two-stage uplift history which started in pre-Stratoid times with initiation of the proto-Danakil block as a NE-plunging asymmetrical dome (Fig. 1A). Pronounced uplift is assumed to have continued in syn- to post-Stratoid times, in combination with subsidence of the Afar accreted crust to the west. The resulting crustal-scale downward bending occurred synchronously with the emplacement of the Stratoid basalts as a volcanic wedge thickening westwards from a few 10's m on the Asa Gayla plateau, up to 100 $\mathrm{m}$ in the Makarassou fault belt, and > $1200 \mathrm{~m}$ in the Asal rift (Fig. 1C) (Zan et al., 1990). Ongoing uplift of the proto-South Danakil block in post-Stratoid times caused the $\sim 800 \mathrm{~m}$ elevation of the initially horizontal Stratoid basalts towards the Day Mountains (Fig. 1A). The onset of uplift might be as young as $125 \mathrm{kyr}$, by correlation with the Middle Pleistocene conglomeratic fans that currently fringe the foot of the South Danakil range in the Tadjoura coastal plain (Fig. 1B) (Gasse and Fournier, 1983).

During the last $3 \mathrm{Ma}$, the SE Afar margin recorded several episodes of extensional faulting in various tectonic settings. The westernmost edge of the proto-South Danakil block (presentday Asa Gayla plateau) developed as a $>10 \mathrm{~km}$-wide half-graben-like structure, filled with a probably thin sequence of Stratoid basalts $\left(S_{2}\right)$, and bounded to the east by an inferred submeridian master fault (Fa on Figs. 1B and 1C). Uplift and erosion events in the footwall block to the east are currently expressed by discrete inliers of deeply incised Lower Stratoid basalts $\left(S_{1}\right)$, resting horizontally on top of Dalha substratum volcanics. Two younger extensional events finally led to the present-day fault arrangement along the SE Afar margin. The <1 Ma Ghoubbet-Asal-Manda-Inakir en echelon subrift pattern along the subdued part of the margin is not detailed here (see Manighetti et al., 1998). More interestingly for the present issue is the structural development of the Makarassou fault system in the upper part of the SE Afar topographic scarp. 
The NS-trending structures of the Makarassou fault system extend through the western flank of a prominent asymmetrical topographic range that culminates at $1800 \mathrm{~m}$ to the south, in the Day Mountains, and slopes down, both northwards at $300 \mathrm{~m}$ in the Dorra plain, and more abruptly westwards at $<100 \mathrm{~m}$ in the Asal-Manda-Inakir rift floor (Fig. 1A). On the Landsat ETM+ satellite image in Fig. 2A, the Makarassou fault system is a $70 \mathrm{~km}$-long fault belt that cuts the frontal part of the Stratoid basaltic wedge. It comprises two adjoining fault subdomains, each $5 \mathrm{~km}$ wide, with contrasting structural styles. The high-density fault subdomain to the east encloses a dense network of anastomosed and sigmoidal faults, about 5 $\mathrm{km}$ long on average. It is separated from the tabular Stratoid basalts of the Asa Gayla plateau via the highly segmented fault $\mathrm{Fb}$ in Fig. 1C. Fault arrangement is more regular in the western subdomain where four wider blocks are bounded by linear, and less segmented faults, $>15 \mathrm{~km}$ in length. There, the westerly-tilted Stratoid surfaces show remnants of NW-SE (Asal-type) structures that are sharply cut, and thus post-dated, by the submeridian Makarassou bounding faults (Fig. 2C). The northern termination of the Makarassou fault belt in the Dorra plain (Fig. 1B) is locally sealed by undeformed Manda Inakir basalts, $>0.87 \mathrm{Ma}$ in age (in Vellutini et al., 1995).

The $40 \mathrm{~km}$-long transect in Fig. 1C cuts at high angle the widest exposed section of the Makarassou fault system. Topography is dominated by a westerly-facing monoclinal flexure that lowers the Stratoid surface to about 900 m, from the Asa Gayla plateau down to the Asal rift floor. The hinge line of the Makarassou flexure approximately coincides with the NStrending trace of fault $\mathrm{Fb}$ (Fig. 2A). The two fault subdomains correspond to a marked shallowing of topography westwards, with a flexure gradient decreasing from $\sim 1^{\circ} / \mathrm{km}$ to $<0.5 \% \mathrm{~km}$. However, the most specific attribute of the Makarassou faults is the easterly (outward) dip of 21 extensional structures (out of a total of 29). With the exception of marginal horst-graben structures in the crestal zone to the east, the antithetic fault network occurs strictly through the downflexed part of the cross-section (Fig. 1C). The resulting inward-dipping Stratoid blocks are arranged in a domino configuration, with a mean spacing of $\sim 500 \mathrm{~m}$, and rotated lava dips as high as $30^{\circ}$, in the upper and steepest part of the flexure (Fig. 2B). Mean fault block width increases, up to $1 \mathrm{~km}$, in the western subdomain, concomitant with decreasing lava dips $\left(10^{\circ}\right.$ in average $)$. Average fault dip is about $70^{\circ} \mathrm{E}$, and remains nearly constant across-strike. Topographic fault scarps extracted from the ASTER 3D 
From the new dataset above, the SE Afar margin is inferred to comprise two distinct extensional fault networks that differ in terms of geometry, timing and kinematics. The AsalManda-Inakir fault pattern bounds NW-SE-oriented en echelon horst/grabens, orthogonal to the $\mathrm{N} 30^{\circ} \mathrm{E}$ regional extension (e.g. Jestin et al., 1994), in the Afar depressed axis. In contrast, the Makarassou extensional fault network is typically characterized by : (1) its spatial association with a riftward-facing monoclinal flexure, (2) its outward-dipping attitude, away from the rift axis, (3) its NS orientation, parallel to the flexure axis, and oblique to the regional extension, and (4) its relatively young age with respect to the Asal structures.

Most of these structural features display striking similarities with those of coastal flexures involving SDRS-type magmatic prisms along VRMs (Mutter, 1984). However, one specific aspect of the Makarasou fault-flexure system is the lack of exposed mafic dyke swarms, but these latter probably exist at depth, beneath the Stratoid fissural-type basalts.

These analogies lead us to evaluate whether the models applied to nascent VRMs could be valid for the SE Afar volcano-tectonic pattern. Given the location of the Makarassou flexure along the western edge of the Asa Gayla plateau, i.e. close to the hinge line marking the limit of pronounced lava thickness towards the magmatically-accreted rift domain, we infer that magma-assisted processes acted as driving forces for riftward-facing flexuring along the western flank of the South Danakil block. By analogy with the isostatic model of Palmason (1980), it is suggested that crustal downwarping along the SE Afar margin was the flexural response to differential loading of the magmatically-accreted crust during the Stratoid (3-1 Ma), and even Dalha (8-4 Ma), flood basalt activity (Fig. 3C). Additional parameters are thought to have interacted during flexuring, and to be responsible for the finite geometry of the Makarassou fault-flexure system. Its NS orientation, oblique to the regional extension, is

160 believed to have followed preexisting structural fabrics. Indeed, the extensional rejuvenation of inherited submeridian faults, such as those cutting the Mablas volcanics to the east, likely accounts for the inferred syn-Stratoid bounding fault Fa (Figs. 1C and 3A). A steep and similarly-trending weakness zone $(\mathrm{Fb})$ is suspected to occur at depth, beneath the hinge line of the flexure, further west. This resulted in an extensional monocline, analogous to those developed above the upward-propagating tip of a blind normal fault (Willsey et al., 2002).

166 Dominantly dip-slip displacement, down to the west, and probably $>500 \mathrm{~m}$, likely occurred

167 along the steep discontinuity $\mathrm{Fb}$, in order to accommodate part of the downflexed bending of the Stratoid sequences at the surface. Assuming that the Makarassou flexure nucleated above 
a steep weakness zone satisfactorily accounts for (1) its relative tightness $(\sim 10 \mathrm{~km})$ with respect to its total length, and (2) its concave profile, with higher flexure gradients in its upper part.

172 The discontinuity $\mathrm{Fb}$ is believed to have once breached the monocline along a surface 173 breaking zone, currently outlined by the crestal horst-graben pattern. The network of 174 antithetic normal faults, splaying upwards into the immediate hangingwall of fault $\mathrm{Fb}$, 175 resemble those directly observed, or obtained experimentally, in extensional monoclines 176 (Withjack et al., 1990; Kaven and Martel, 2007). But, their nucleation and development in the downflexed Stratoid lava pile were probably controlled by volcanic structures, as follows. Provided that the wedge-shaped pile of initially horizontal (Dalha-Stratoid) lava flows rotated westwards, towards the axis of the active magmatic zone, during early flexuring, the cooling joint pattern, known to generally act as tension fractures under tensile stress (Forslund and Gudmundsson, 1992 ; Le Gall et al., 2000), likely evolved from an initially vertical attitude to an easterly-inclined position with time (Fig. 3B). The decreasing dip attitude of the joint pattern at depth resulted in a listric-shaped joint trajectory which might have later triggered nucleation of normal faults, dipping away from the subsiding rift axis to the west, once submitted to the $\mathrm{N} 30^{\circ} \mathrm{E}$-directed extension.

The isostatic, instead of tectonic, model proposed here for the Makarassou flexure is reinforced by the fact that structural evidence are currently absent for a continentward-facing detachment underlying the Stratoid wedge, as argued in the 'roll-over anticline' model applied to SDRS prisms elsewhere (Geoffroy et al., 1998). Furthermore, the constant and steeply-dipping attitude of extensional faults throughout the Makarassou flexure is at odds with highly rotated hangingwall structures, typically developed above the frontal part of a detachment (McKlay, 1996).

193 From the age of pre- (3-1 Ma) and post-flexuring (>0.87 Ma) basalts, the maximum duration 194 of the Makarassou flexure is 2Ma, i.e. as similarly stated for others VRMs (Lenoir et al., 2003 ; Klausen, 2009). Such a short time span suggests that regional strain rates were relatively high during flexuring along the SE Afar margin, probably in relation with

198 The magma-driven vertical tectonics and riftward-facing flexuring that operated during the last $3 \mathrm{Ma}$, along the eastern flank of the Asal-Manda Inakir future plate boundary, are confidently regarded as the stuctural expression of an incipient VRM in SE Afar. The inferred embryonic stage of continental breakup is in agreement with previous assessments about the transitional type of the Stratoid flood basalt series, and the thinned character of the Afar crust. 


\section{Acknowledgments}

205

206

Funding and logistical support from CERD of Djibouti (Dir. Dr Mohamed Jalludin), and the MAWARI program, are appreciated. Thanks also to the reviewers G. Eagles, A. Gudmundsson and J. Rowland, and to the Associate Editor A. Nicolas for helpful and constructive comments that improved a previous version of the manuscript. Stefan Lalonde is warmly thanked for polishing the English.

\section{References cited}

Barbéri, F. and Varet, J., 1977. Volcanism of Afar :small-scale plate tectonics implications. Geol. Soc. Am. Bull., 88, 1251-1266.

Coffin, M.F. and Eldhom, O., 1994. Large igneous provinces : Crustal structure, dimensions and external consequences. Rev. Geophys., 32, 1-36.

Dugda, M.T. and Nyblade, A.A., 2006. New constraints on crustal structure in eastern Afar from the analysis of receiver functions and surface waves dispersion in Djibouti. In : The Afar Volcanic Province Within The East African Rift System (G. Yirgu, C.J. Ebinger, P.K. Maguire, eds). Geol. Soc. London, Sp. Pub., 259, 239-251.

Forslund, T. and Gudmundsson, A., 1992. Structure of Tertiary and Pleistocene normal faults in Iceland. Tectonics, 11, 57-68.

Gasse, F. and Fournier, M., 1983. Sédiments plio-quaternaires et tectonique en bordure du Golfe de Tadjoura, République de Djibouti. Bull. Centres Recherche ExplorationProduction Elf-Aquitaine, 7, 285-300.

Geoffroy, L., Gélard, J.P., Lepvrier, C. and Olivier, P., 1998. The coastal flexure of Disko (West Greenland), onshore expression of the 'oblique reflectors'. J. Geol. Soc. London, 155, 463-473.

Jestin, F., Huchon, P. and Gaulier, J.M., 1994. The Somalia plate and the East African Rift System : present kinematics. Geophys. J. Intern., 116, 637-654.

Kaven, J.O. and Martel, S.J., 2007. Growth of surface-breaching normal faults as a threedimensional fracturing process. J. Struct. Geol., 29, 1463-1476.

Klausen, B., 2009. The Lebombo monocline and associated feeder dyke swarm : Diagnostic of a successful and highly volcanic rifted margin ? Tectonophysics, 468, 42-62. 
Le Gall, B., Le Turdu C., Richert J.P., Tiercelin J.J., Gente P., Sturchio P. and Stead, D., 2000. A morphotectonic study of an extensional fault zone in a magma-rich rift type : the Baringo Trachyte Fault System, Central Kenya Rift. Tectonophysics, 320, 87-106.

Lenoir, X, Féraud, G. and Geoffroy, L., 2003. High-rate flexure of the East Greenland volcanic margin : constraints from ${ }^{40} \mathrm{Ar} /{ }^{39} \mathrm{Ar}$ dating of basaltic dykes. Earth and Planet. Sc. Lett., 214, 515-528.

Manighetti, I., Tapponnier, P., Gillot, P.Y., Jacques, E., Courtillot, V., Armijo, R., Ruegg, J.C. and King, G., 1998. Propagation of rifting along the Arabia-Somalia plate boundary : Into Afar. J. Geophys. Research, 103, 4947-4974.

McKlay, K.R., 1996. Recent advances in analogue modelling : uses in section interpretation and validation. In : Modern Developments In Structural Interpretation, Validation And Modelling. (P.G. Buchanan and D.A. Nieuwland, eds.). Geol. Soc. London, Sp. Pub., 99, 201-225.

Mohr, P., 1989. Nature of the crust under Afar : new igneous, not thinned continental : Tectonophysics, 167, 1-11.

Mutter, J.C., 1984. Seaward dipping reflectors and the continent-ocean boundary at passive continental margins. Tectonophysics, 114, 117-131.

Nielsen, T.F. and Brooks, C.K., 1981. The East-Greenland rifted continental margin : an examination of the coastal flexure. J. Geol. Soc., London, 138, 559-568.

Palmason, G., 1980. A continuum model of crustal generation in Iceland : Kinematics aspects. J. of Geophys., 47, 7-18.

Tapponnier, P. and Varet, J., 1974. La zone de Mak'arrassou en Afar, un équivalent émergé des failles transformantes océaniques. C. R. Acad. Sc., Paris, 274, 209-212.

Vellutini, P., Piguet, P. and Recroix, F., 1995. Carte géologique de la République de Djibouti au 1/100 000. Feuille de Dorra. In: Notice explicative. (BRGM, eds). Service Géologique National, Orléans, 85 pp.

White, R.S. and McKenzie, D.P., 1989. Magmatism at rift zones : The generation of volcanic continental margins and flood basalts. J. Geophys. Res., 94, 7685-7729. 
Willsey, S.P., Umhoefer, P.J. and Hilley, G.E., 2002. Early evolution of an extensional monocline by a propagating normal fault : 3D analysis from combined field study and numerical modeling. J. Struct. Geol., 24, 651-669.

Withjack, M.O., Olson, J. and Peterson, E., 1990. Experimental models of extensional forced folds. Am. Assoc. Pet. Geol. Bull., 74, 1038-1054.

Zan, L., Gianelli, P., Passerini, C., Troisi, A. and Haga, O., 1990. Geothermal exploration in the Republic of Djibouti: thermal and geological data of the Hanlé and Asal areas. Geothermics, 19, 561-582.

\section{Figure captions}

Fig. 1A. ASTER digital elevation model of the SE Afar rift in Djibouti (vertical resolution 15 $\mathrm{m}$ ). Topography ranges from $-150 \mathrm{~m}$ (Asal) up to $1800 \mathrm{~m}$ (Day Mountains). See nomenclature in Fig. 1B. The white line shows the limit of Stratoid basalts (onshore). Ticks are inside the volcanic area. Note its obliquity with respect to the South Danakil reliefs. Fig. 1B. Structural sketch of the SE Afar margin in Djibouti. 1. Moussa Ali volcanics ; 2a. 3-1 Ma Stratoid and Gulf basalts; 2b. Lower Stratoid basalts; 3. >3 Ma synrift volcanics, 3a. Dalha basalts, 3b. Mablas Fm. ; 4. Main faults, 5. Makarassou fault system. A., Asal ; AGP., Asa Gayla plateau ; AS., Ali Sabieh ; D., Dorra ; Dj., Djibouti ; DM., Day Mountains ; G., Ghoubbet ; GT., Gulf of Tadjoura ; MA., Moussa Ali volcano ; MFS., Makarassou fault system ; MI., Manda Inakir; T., Tadjoura. Trace of section 1C is drawn. Inset shows accretionary axes in the Afar Triple junction. 1C. Structural cross-section of the central part of the Makarassou fault system. Topography is extracted from the ASTER DEM. 1 and 2. $S_{1}$ and $S_{2}$ Stratoid basalts, respectively. 3. Dalha basalts. Vertical exaggeration $\sim 4$. Location in Fig. 1B.

Fig. 2A. Map trace of the Makarassou fault belt on the eastern flank of the Asal-Manda Inakir rift framework (Landsat ETM+ image, $15 \mathrm{~m}$ resolution). The dashed black line is the trace of the flexure hinge line, close to the trace of fault $\mathrm{Fb}$. 2B. Field view of a closelyspaced network $(\sim 500 \mathrm{~m})$ of three Stratoid tilted blocks (dip $\left.\sim 15^{\circ} \mathrm{W}\right)$, bounded by easterly-facing extensional faults. View looking south. The main fault scarp in the back is about $150 \mathrm{~m}$ high. Location in Fig. 1C. 2C. Focussed view of the Landsat ETM+ image (in Fig. 2A) showing Makarassou submeridian normal faults cutting NW-SEtrending Asal horst-graben structures. 
298 Fig. 3A. Sketch structural map of SE Afar emphazing the role of inherited NS discontinuities on (1) the propagation of the Aden and Ghoubbet-Asal-Manda-Inakir incipient plate boundaries, and (2) initiation of the corresponding volcanic rifted margin (Makarassou belt). 1. <1 Ma rifted zones ; 2. Makarassou flexure ; 3. Onshore distribution of 3-1 Ma Stratoid and Gulf basalts; 4. Pre-Stratoid volcanics. A. Asal ; Ar. Arta ; G. Ghoubbet; MFS. Makarassou fault system; MI. Manda Inakir; MT. Maskali transform. 3B. Conceptual model for the origin of outward-dipping extensional faults in wedges of flood basalts. 3C. Development of riftward-flexuring and antithetic extensional faulting along the SE Afar margin, as a consequence of magma-driven isostatic loading, and reactivated heterogeneities. 1. Stratoid basalts (3-1 Ma); 2. Dalha basalts (8-4 Ma); 3. Volcanic substratum (>8 Ma). 

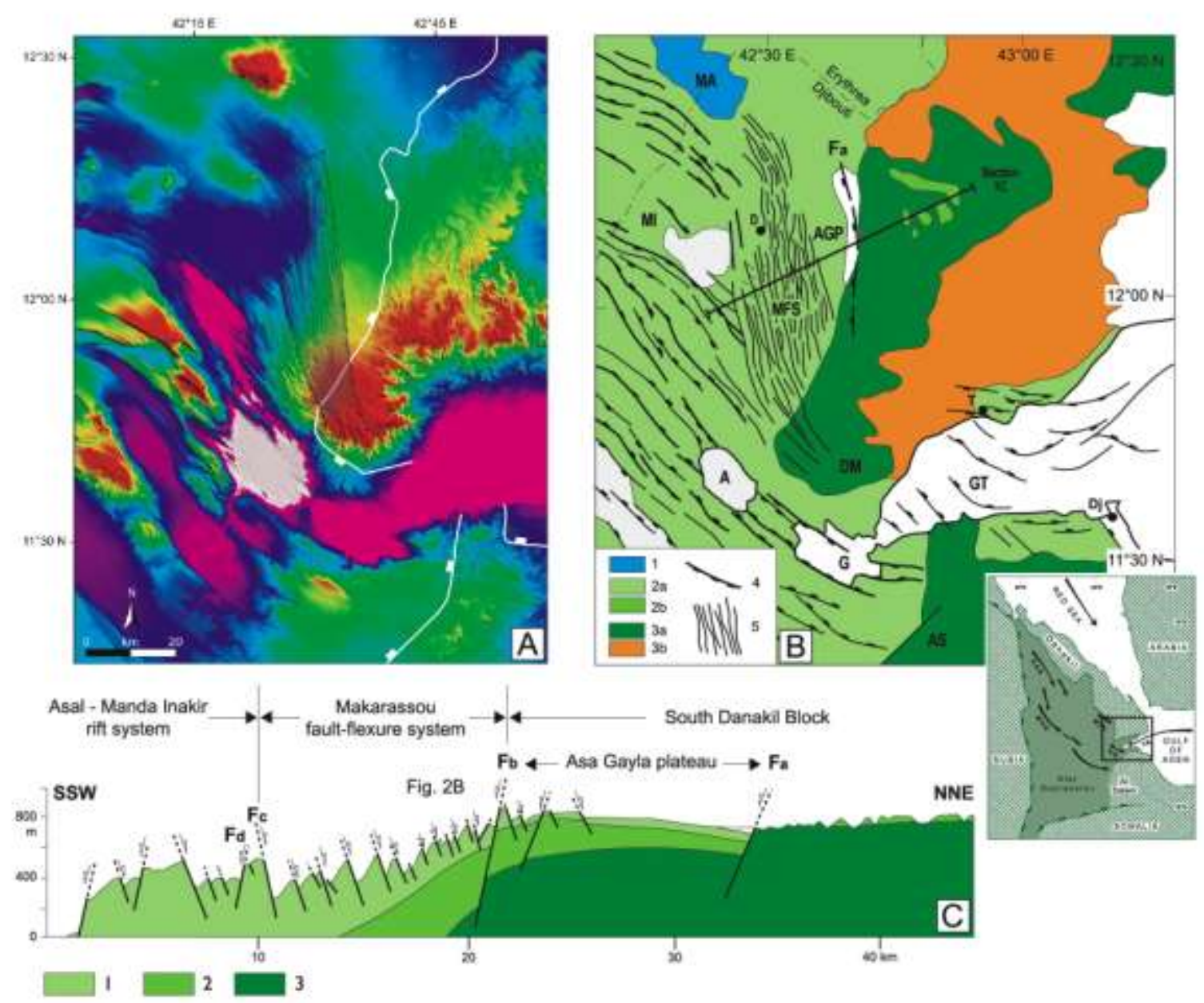

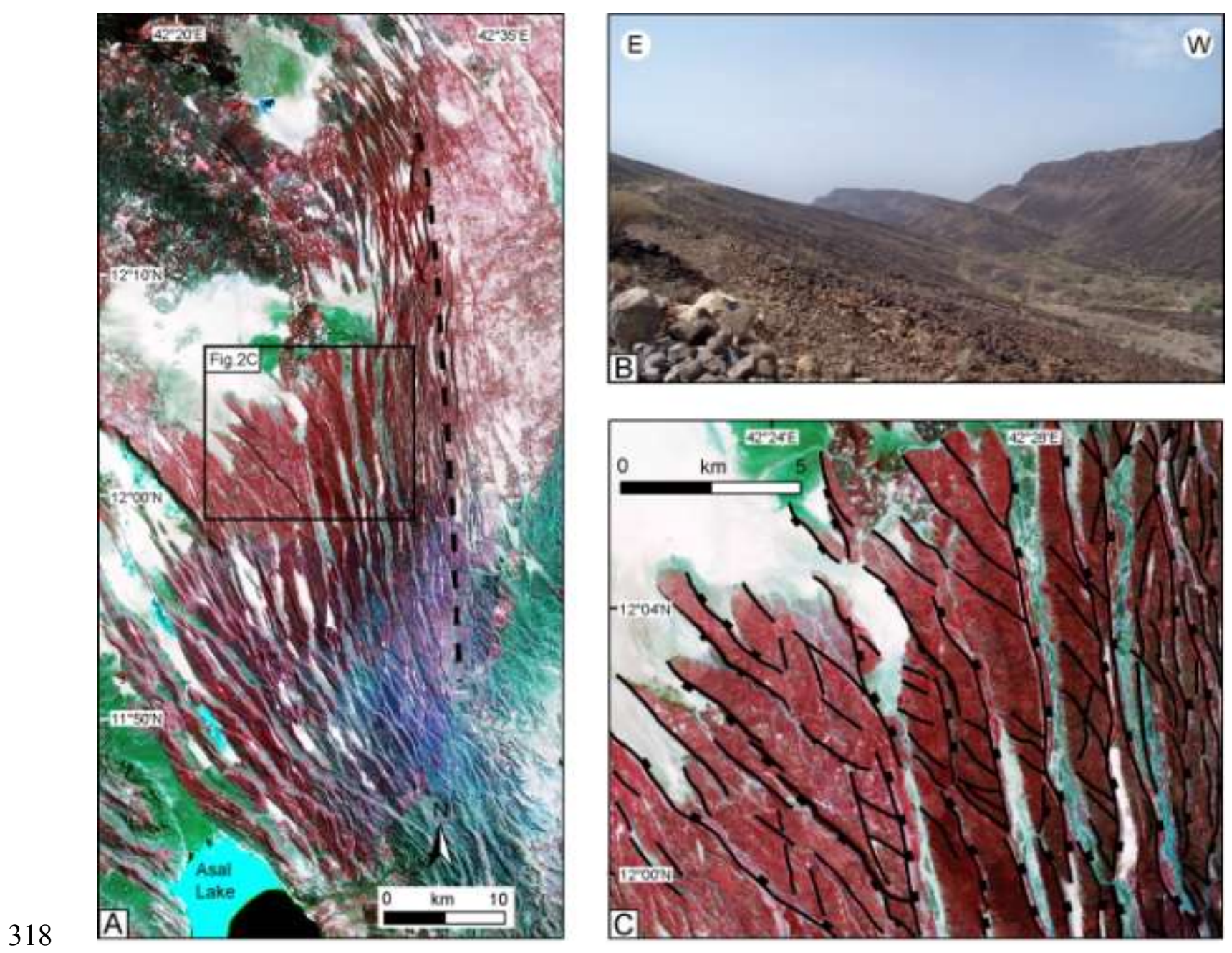

319

320

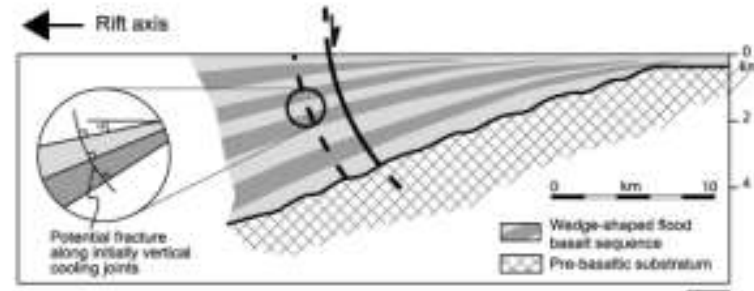

w

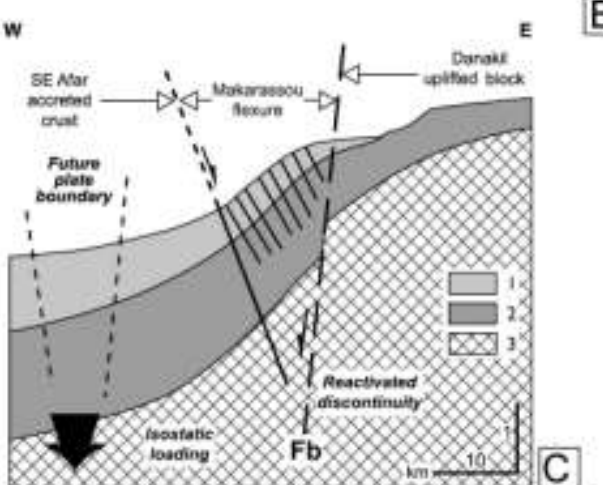

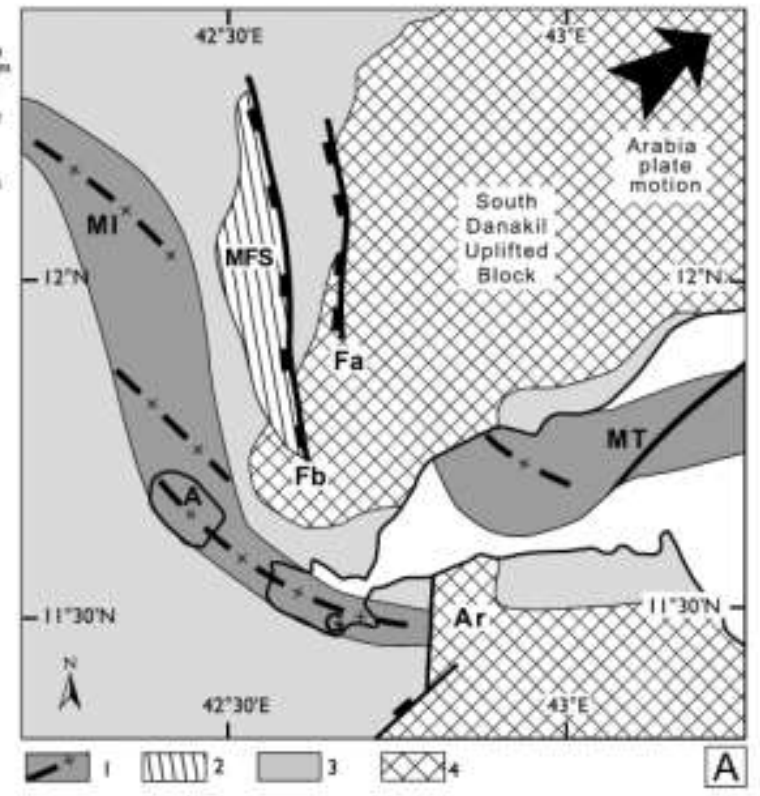

